Czigányik, Zsolt. "From the Bright Future of the Nation to the Dark Future of Mankind: Jókai and Karinthy in Hungarian Utopian Tradition." Hungarian Cultural Studies. e-Journal of the American Hungarian Educators Association, Volume 8 (2015): http://ahea.pitt.edu DOI: 10.5195/ahea.2015.213

\title{
From the Bright Future of the Nation to the Dark Future of Mankind: Jókai and Karinthy in Hungarian Utopian Tradition ${ }^{1}$
}

\author{
Zsolt Czigányik
}

\begin{abstract}
After defining utopianism, Czigányik provides a brief introduction to Hungarian utopian literature. Though he discusses Tariménes utazása ['The Voyage of Tariménes'], written by György Bessenyei in 1804, the utopian scenes of Imre Madách's Az ember tragédiája ['The Tragedy of Man', 1862] and Frigyes Karinthy's short utopian piece, Utazás Faremidoba ['Voyage to Faremido', 1916], the bulk of the paper deals with Mór Jókai's monumental novel, A jövö század regénye, ['The Novel of the Century to Come', 1872]. Jókai, who had taken an active part in the 1848 uprising, depicts in this novel a future world of an imaginary twentieth century, where Hungary has primacy within the Habsburg empire (with the emperor king being Árpád Habsburg) and the invention of the airplane (by a Hungarian) brings lasting peace, stability, and prosperity to the world. Besides introducing the Hungarian utopian tradition, the paper will reflect upon the role of individuals in imagined societies and how an agency-centered narrative overwrites the essentially structuralist view of history that usually permeates utopias.
\end{abstract}

\section{Keywords: Utopia, Dystopia, Jókai, Karinthy, Intentionalism}

Biography: Zsolt Czigányik received his M. A. and Ph. D. in Modern English Literature from ELTE University, Budapest. He has published mostly on twentieth century dystopian literature and also on literary censorship in Hungary. He has taught courses on modern and contemporary English literature and on utopianism at ELTE and at the Central European University (CEU), Budapest. In 2013-2014 he was Humanities Initiative Fellow at the Institute for Advanced Study at CEU. Currently he is working on a monograph on Hungarian utopianism.

While Hungarian literature might not be well known within European literature, Hungarian utopian literature is not even very well known within Hungary itself. The isolation is partly because Hungarian utopian and dystopian works are rarely examined in the context of a contiguous tradition but rather tend to be studied only within the larger oeuvre of their authors.

${ }^{1}$ The research was carried out under the auspices of the Humanities Initiative Fellowship of the Institute for Advanced Studies at Central European University, Budapest. www.ias.ceu.hu 
Czigányik, Zsolt. "From the Bright Future of the Nation to the Dark Future of Mankind: Jókai and Karinthy in Hungarian Utopian Tradition." Hungarian Cultural Studies. e-Journal of the American Hungarian Educators Association, Volume 8 (2015): http://ahea.pitt.edu DOI: 10.5195/ahea.2015.213

Here such works are often considered of lesser importance, especially compared to realistic novels, which still set the standard for the common reader and for many critics as well. My research attempts to establish a coherent nineteenth and twentieth century utopian tradition that focuses on the relationship of the individual and the collective in the light of a specifically Hungarian and Central European experience of social and political structures. My goal in this paper is twofold: I would like to briefly introduce the Hungarian utopian tradition of the nineteenth and early twentieth centuries by presenting the most important representatives of the genre, and analyze in greater detail the longest but somewhat neglected classic of Hungarian utopianism, Mór Jókai's A jövö század regénye ['The Novel of the Century to Come', 1872].

The concept of utopia I use extends beyond the literary genre and includes social phenomena and political ideology. In contrast to many other genres of literature, when talking about utopia one feels that the term needs to be defined, because utopia is not exclusively a literary genre. The term first appeared as a neologism in 1516, almost exactly five hundred years ago, in the title of Thomas More's Utopia, a book which was to achieve seminal importance. The title, and hence the term, can be understood both as "good place" and "no-place," an ambiguity which has been an inherent feature of the genre ever since (Vieira 2010). While the term utopia may be five hundred years old, the concept is perennial: scholars find its traces in ancient writings including the Old Testament and even in earlier writings, in myths and fairy tales. Utopia is also understood as an anthropological phenomenon found in various areas of human culture. Utopian works of literature, in fact, represent manifestations of man's eternal longing for a better place and for a better life, or as Fátima Vieira argues: "[it is] a manifestation of the wishing nature of man" (2010: 20). Since Lyman Tower Sargent's influential 1994 article "The Three Faces of Utopianism Revisited," scholars seem to agree that the literary representations of utopia are only one aspect of a broader concept called utopianism, and that other components, namely real utopias or communities (that is utopian practice) and utopian ideologies (social theory) are at least equally important. It is also a point of agreement in the interdisciplinary study of utopianism that in the case of a literary piece, benefit is to be gained from the study of the content rather than the form. The present study also follows these lines in highlighting the social and political aspects of the few utopian pieces scattered around in nineteenth and early twentieth century Hungarian fiction and drama.

There is an underlying ambiguity in utopia; the term can refer to a good place and its opposite simultaneously. A standard definition of utopia would mention a place, or rather an alternative reality that is significantly better than the reality - usually political - experienced by the writer (and presumably, the readers). However, the utopian reality described in a given work is very often not really desirable, and one does not even presume that it was intended to be desirable by its creator (let us set aside for the time being the complications arising from dealing with the intentions of the author, a fallacy committed by many scholars of literature). In fact, this inevitable ambiguity may be considered as one of the virtues of the genre; as Miguel Abensour argues, a dogmatic reading is prevented by utopia's constant oscillation between eutopia and outopia, the "good place" and the "no place" (2008: 406). A further point of this interpretative oscillation is the "bad place," the negative utopia or dystopia, the alternative reality that not only is non-existent, but also is not desired. In fact, twentieth century utopian literature is predominated by dystopian images and constructions, having become extremely popular both on the screen and on the page, whereas honest, straightforward eutopias are hard to find. Though contemporary examples of utopia are not a subject of the present paper, the ambiguity of the interpretation of the terminology will be dealt with. The focus of this article is Mór Jókai's $A$ 
Czigányik, Zsolt. "From the Bright Future of the Nation to the Dark Future of Mankind: Jókai and Karinthy in Hungarian Utopian Tradition." Hungarian Cultural Studies. e-Journal of the American Hungarian Educators Association, Volume 8 (2015): http://ahea.pitt.edu DOI: 10.5195/ahea.2015.213

jövö század regénye ['The Novel of the Century to Come'], a positive utopia, exactly the kind that became marginal in the twentieth century. Such positive utopias or eutopias are the products of an earlier age, and they are mostly read ironically today, but an underlying human feature, a "longing for a better world," is clearly manifested in such works.

\section{The Beginning of Hungarian Utopianism}

The first major Hungarian utopian work was written in 1804 by György Bessenyei (17471811), but it did not appear in print until 1930 due to Habsburg censorship. Bessenyei was an important playwright and a significant figure in the Hungarian Enlightenment. In his utopian novel, Tariménes utazása ['The Voyage of Tariménes'] Bessenyei confronts contemporary Hungarian reality with the ideals of a rationally governed, enlightened state. The hero of Bessenyei's book, Tariménes, is a student and traveler who arrives in a fictional country called Totopos, an ideal community, where the fortune of one person does not cause the misfortune of others. In this modest, pragmatic pseudo-Hobbesian utopia, where peace is presented as a natural state of affairs in a society that has achieved an harmonious state of existence, civilization is seen as being superior to the natural state of affairs, serving the individual's happiness as opposed to the wild and chaotic state of uncivilized people. Advanced civilization is presented as an understanding of the laws of nature that enables man to transcend and excel nature. The harmony of Totopos is based on the coherence of society, which is hierarchical, but the hierarchy is meant to serve the common good of all. The king of the neighboring country even criticizes the queen of Totopos, claiming that "she does not rule over her people, but she serves them" [nem uralkodik, hanem szolgál], whereas, in his understanding, power should stem from the enslavement of captive people, where coercive force is naturally used (Bessenyei, 1953: 422, my own translation). In the utopian society depicted by Bessenyei the goal of government is to enhance the common happiness. The happiness of the ones above in the hierarchy cannot be achieved without the happiness of the ones below. It is easy to see consequently why Habsburg censorship prevented the publication of the book.

\section{Utopia on Stage: Az ember tragédiája ['The Tragedy of Man']}

The Tragedy of Man presents human history as a series of failed attempts to improve human existence. With Bessenyei's text kept from the larger public until 1930, the first important literary work that was partly utopian is a drama written in 1862 by Imre Madách (1823-1864), titled Az ember tragédiája ['The Tragedy of Man']. To this day, the piece is considered the most important Hungarian drama, not just in Hungary, but around the world as it has been translated into seventeen languages. It is worth mentioning that in England the "Bloomsbury intellectuals" showed an interest in Madách, with the play first published in English by Virginia and Leonard Woolf's Hogarth Press in 1933 (for a more contemporary English translation by George Szirtes see http://mek.oszk.hu/00900/00918/html/). The Tragedy of Man expounds a complex allegory of mankind's history as the first human couple, Adam and Eve, travel through space and time visiting the most important instances of human history. The journey includes, amongst other venues, the building of the pyramids in Egypt, ancient Rome and early-seventeenth century Prague, where the astronomer Johannes Kepler is obliged to deal with astrology, a quasi-science he despises. The travels of Adam and Eve also include London in the industrial revolution, but the achievements of technological advancement are seen as disappointing as they result in capitalism, which is described as the rule of rapacity that ends in a general danse macabre. One of the final scenes of the play takes place in the Phalanstère, the utopian community envisioned 
Czigányik, Zsolt. "From the Bright Future of the Nation to the Dark Future of Mankind: Jókai and Karinthy in Hungarian Utopian Tradition." Hungarian Cultural Studies. e-Journal of the American Hungarian Educators Association, Volume 8 (2015): http://ahea.pitt.edu DOI: 10.5195/ahea.2015.213

by Charles Fourier (1772-1837), a most influential utopian socialist philosopher. Phalanstère was imagined to be an ideal place for a community to live and work together in a harmonious way, but Madách highlights the dystopian and oppressive aspects of this imaginary community. In The Tragedy of Man phalanstère is a place where conformity is forced upon the inhabitants and human creativity is curbed; Michelangelo is made to carve identical legs for chairs. The utopian attempt enhances the misery of mankind, utopia becomes another failed attempt to make life happier or at least more endurable.

Failed political aspirations that keep turning into oppressive systems form the backbone of Madách's play. The Tragedy of Man was called by Erika Gottlieb "a romantic precursor of the dystopian fiction of the twentieth century, as it demonstrates the continuous interaction between utopian and dystopian perspectives in the numerous political dreams of Messianism that inevitably turn into the nightmares of dictatorship" (2001: 44). Gottlieb highlights the play's "consistent dialectic between aspirations and disillusionment," with the thinking of the masses continuously violating the development of the ideas of great minds (2001: 46). Political aspirations keep resulting in dystopian forms of oppression which prevail over utopia in all ages of mankind, including the future. Madách's play is a perfect example for Roland Schaer's definition of utopia, who claims that utopian literature is a "dialectic of dream and nightmarebest and worst of possible worlds" (Schaer, 2000: 6). The dialectic of the play works the following way: hope is always suggested explicitly, yet the implicit occurrences do not support optimism. But pessimism does not prevail either, as humanity keeps surviving all dictatorships and man always maintains a will for new beginnings. The new era that follows every beginning nevertheless keeps resulting in unhappy states for mankind in newer and newer ways: dreams keep turning into nightmares, but aspirations do not die.

\section{Peace and Future Technology in Utopian Fiction}

The utopian impulse in Hungarian literature culminates in A jövö század regénye ['The Novel of the Century to Come'] written by Mór Jókai (1825-1904). The novel is the longest utopia of Hungarian literature (some eight hundred pages long) and it began to be published in a serialized form in 1872, a decade after the first performance of Madách's drama. Jókai was the most important - and certainly the most prolific - novelist in Hungary during the second part of the nineteenth century. His utopian novel was very popular after its publication and influenced a number of writers until the mid-twentieth century. Mostly due to its nationalism and anti-Russian plot, the communist regime considered it dangerous and it was not re-published until a critical edition appeared with explanatory notes in 1981, the previous edition having appeared in 1928. Jókai's novel, which deals with the Austro-Hungarian Monarchy about a hundred years in the future, looks mostly at the political life of an imagined twentieth century. Jókai places the narrative in a rather distant future without changing most of the technical details of his own time: people ride on horseback and use slates for writing, etc. There is only one major technical invention, that of a flying machine. Jókai does not extrapolate technical and scientific progress in general, but looks at the effects of one single major achievement on the life of mankind. Veres (2013:69) claims that Jókai's naively optimistic belief in the overwhelmingly positive effects of technical progress is typical of the utopian literature of the age, and remains prevalent until the First World War. Jókai's utopian novel also resembles the fiction of the contemporary French writer Jules Verne (1828-1905) in as much as the development of technology is of central importance. As Zsuzsa D. Zöldhelyi (1981: 607) states, the great difference between Verne's and Jókai's approach is the focus. The development of technology is important for Jókai for its social 
Czigányik, Zsolt. "From the Bright Future of the Nation to the Dark Future of Mankind: Jókai and Karinthy in Hungarian Utopian Tradition." Hungarian Cultural Studies. e-Journal of the American Hungarian Educators Association, Volume 8 (2015): http://ahea.pitt.edu DOI: 10.5195/ahea.2015.213

and political aspects, whereas Verne mostly concentrates on technology for its own sake, without considering social aspects (with the exception of The Begum's Millions in 1879). It is obvious that the popular French writer had an influence on Jókai, but we cannot consider his work derivative. Even the idea of an electrical flying machine precedes his French counterpart; in Verne's fiction it only appears in Robur the Conqueror published in 1886, more than a decade after The Novel of the Century to Come.

Politically, the major difference of Jókai's novel from the contemporary reality is that in the fictional future Hungary is a country of great importance not just within the AustroHungarian monarchy but throughout Europe. The emperor is Árpád Habsburg, the personal name indicating the importance of the Hungarian half of the Empire by a reference to the leader of the Hungarian tribes that arrived into Central Europe in the ninth century. In the novel the original Árpád becomes so important in the utopian twentieth century that the Roman Catholic Church, which actually moves its center from Rome to Hungary, canonizes this pagan lord. This fictive future can be seen as a political protest by Jókai, who had been an active participant in the 1848 freedom fight against the Habsburgs. He also opposed the dualistic system after the Compromise of 1867, whereby the role of Hungary was dominant over some other nationalities in the Empire, but subservient to Austria. Ironically, maybe he is also protesting contemporary reality: emperor Francis Joseph, who was simultaneously the king of Hungary, did not speak Hungarian. Jókai clearly invented this fantasy world because he was an ardent supporter of Hungarian independence and could not accept Habsburg rule, unless it clearly benefited Hungary. Such a situation he could not imagine otherwise than Hungary having a primacy within the empire. However, the fantasy becomes so ridiculous that it can hardly be interpreted in any other way than as an ironic satire of the contemporary political situation.

The preface of Jókai's book explicitly places the narrative in the context of satirical utopian literature. The function of the preface is quite similar to the first book of Thomas More's Utopia; Jókai lists contemporary problems (wars, armaments race, economic inequality, overpopulation, etc.), and then posits solutions in the form of the utopian construction. The structure of comparing a contemporary dismal reality to a bright, utopian future makes the present appear as a dystopia, exemplifying the rule as elucidated by Krishan Kumar that "[u]topia carried the function of anti-utopia as well: it presented the writer's world negatively, as an anti-utopia, to which utopia is the constructive positive response" (1987:124). In the preface Jókai relates his writing to More, Swift, Campanella, and other utopian writers, and also states that he is aware of the satirical complexion of the tradition. As such, we may view Jókai's work in Tower Sargent's terms as a utopian satire: "a non-existent society described in considerable detail and normally located in time and space that the author intended a contemporaneous reader to view as a criticism of that contemporary society" (1994: 9). Jókai states in his semi-realistic creed that the usual task of fiction is to present a fictive tale as if it were real, whereas his current endeavor aims at presenting something that has not happened "yet", but the reader should feel that it may occur in the future (Jókai 1981: 5). He is also aware of the various forms of displacement, whereby the fictive construction is isolated from empirical reality, and recognizes the dominance of spatial displacement in classical utopian tradition (islands and other unknown parts of the world), but sets out to use a temporal method which involves the use of a geographically realistic setting (see Jókai 1981: 6).

The Darwinian concept of struggle for existence has a central importance in the conceptual framework of Jókai's utopia. Jókai (somewhat emphatically) claims to have studied mankind's most important ideologies and presents them in a framework of perennial wars and 
Czigányik, Zsolt. "From the Bright Future of the Nation to the Dark Future of Mankind: Jókai and Karinthy in Hungarian Utopian Tradition." Hungarian Cultural Studies. e-Journal of the American Hungarian Educators Association, Volume 8 (2015): http://ahea.pitt.edu DOI: 10.5195/ahea.2015.213

struggles. Concrete historical wars and struggles of the immediate past are listed (in America, Italy, or Poland), but struggle is seen as eternal in a Darwinian sense. The elements of this struggle - ranging from the more concrete toward the more abstract notions - are characterized by Jókai (1981: 7-10) in the following ways:

- Armed conflicts induce a general armament involving vast amounts of money and setting almost the whole of the male population in arms - both of which is considered a huge waste.

- On a Marxist basis, a struggle between capital and work (or workers) is recognized.

- Besides the economic struggle, there is a struggle between the moral basis of society and the decay and corruption fueled by the great differences between members of a society.

- The growth of population (curiously linked to the loosening of family morals) results in an eco-dystopia by involving an ecological struggle of epic scale between man and earth (a notion that will recur in Karinthy's Faremido).

- Colonialism is presented as an eternal struggle between the old and the new world.

- All the above culminate (and also find their basis) in an eternal struggle within man: the struggle of the godlike and animal side of man. The godlike is presented as representative of progress and enlightenment, the common good of society (both in the form of nation and mankind), whereas the animal is represented by forces of Nihil that deny all abstractions (God, nation, otherworld, law, family, honor, etc.). Such abstractions as past or future are also denied by these forces in the name of the present.

The binary oppositions point toward an underlying struggle of positivism and idealism. The final and almost metaphysically abstract underlying struggle between the godlike and animal side of man represents the tensions that constitute the basis of Jókai's utopian construction. All the struggles culminate in the struggle between positivism and symbolism, or rather, between the overall validity of rational knowledge and the claim that such knowledge always remains insufficient. This opposition is in line with George Steiner's comment in After Babel that the power of human language is its ability to construct counterfactuals:

It is the miraculous - I do not retract the term - capacity of grammars to generate counter-factuals, 'if'-propositions and, above all, future tenses, which have empowered our species to hope, to reach far beyond the extinction of the individual. We endure, we endure creatively due to our imperative ability to say "No" to reality, to build fictions of alterity, of dreamt or willed or awaited 'otherness' for our consciousness to inhabit. It is in this precise sense that the utopian and the messianic are figures of syntax (2013: 13; see also Baccolini and Moylan [2003: 236]).

The counter-factual nature of language — and hence human thought — is not only a necessary prerequisite of the genre of utopia, but also of the greater future of humanity in the biological, cultural and social-political senses. The understanding of this principle is not only relevant for the structure of Jókai's utopian fiction or those of other Hungarian works in the genre, but it is of general significance in utopian literature. The importance of the counter-factual nature of language can particularly be seen in Sándor Szathmári's Kazohinia, first published in 1941, which I will not discuss in the present paper. (For a review of Kazohinia see AHEA 6 (2013) http://ahea.net/e-journal/volume-6-2013.) And when counterfactuals are denied or considered 
Czigányik, Zsolt. "From the Bright Future of the Nation to the Dark Future of Mankind: Jókai and Karinthy in Hungarian Utopian Tradition." Hungarian Cultural Studies. e-Journal of the American Hungarian Educators Association, Volume 8 (2015): http://ahea.pitt.edu DOI: 10.5195/ahea.2015.213

superfluous by a society, their absence creates the opposite of utopia, such as in Karinthy's Voyage to Faremido, which will be discussed below.

The optimism of Jókai's book is based on a faith in scientific progress, which is an essentially metaphysical faith. Together with an acceptance of the importance of abstractions and alterity, a faith in science also permeates Jókai's utopia - a faith that was on the decline in Western Europe by the end of the nineteenth century. Friedrich Nietzsche in The Genealogy of Morality [Zur Genealogie der Moral, 1887] claims that "[i]t is still a metaphysical faith that underlies our faith in science - and we men of knowledge of today, we godless men and antimetaphysicians, we, too, still derive our flame from the fire ignited by a faith a millennia old, the Christian faith, which was also Plato's, that God is truth, that truth is divine" (quoted in Booker 1994: 8). Jókai's utopianism is based on the same assumptions, hence the positive forces working on the progress of mankind (necessarily on a scientific basis) have to confront the forces working against it, and the confrontation is both scientific-technical and religious-ideological in nature.

The gigantic struggle between the forces working for the progress of humanity and the ones striving against a better future reaches a peaceful standstill through the invention of a flying machine. The first part of The Novel of the Century to Come describes the eternal struggle that manifests itself in various - mostly political - conflicts which constitutes the complex plot of the novel. A faith in science and the positive effects of the advancement of technology permeates the narrative, where lasting peace comes through a new invention, namely the airplane, whose creation has been an endeavor of mankind from time immemorable. Although balloons had existed since the eighteenth century and a number of experiments were carried out in the nineteenth century with heavier-than-air machines, the first reliable aircraft appeared only decades after Jókai's book (the Wright brothers had begun experimenting with powered flight in 1903, while Louis Bleriot crossed the English Channel in 1909). Flying is depicted by Jókai as something that brings fundamental changes into the life of mankind: by making communication and commerce simpler, it has a huge and utterly positive globalizing effect. Flying for Jókai is a spiritual experience, not dissimilar to religious phenomena following from Nietzsche's assertion that there is an underlying religious aspect of science. "...I only felt I flew. I felt something of salvation [én csak azt éreztem, hogy repülök. Valamit éreztem az üdvösségböl] (Jókai, 1981: 152). Spirit is also equated with the air's electricity, with electricity presented as something magical, something beyond rational comprehension. The principle of flying by the use of electricity (with birdlike flapping wings), the beauty of the machine and the majestic experience of flying are all elaborated in great detail in Jókai's novel. One of the chief impacts of flying is making warfare absurd; by making defense and hence war impossible, it provokes a general disarmament.

The Novel of the Century to Come combines utopia with fairy tale-like magic. The construction of a reliable flying machine had led to failures before an appropriate substance, the utopian material called ichor was discovered. The term ichor originally denotes an ethereal golden fluid, the blood of immortals in Greek mythology; after its discovery by the protagonist of the novel, Dávid Tatrangi, a perfectly reliable electrical flying machine is built. Ichor is an element of fairy tale-like magic, another example for the combination of science and myth. Beyond helping in the invention of the airplane, ichor has a miraculous effect on humans; a splinter of it can cause an individual to become bedridden for six whole weeks, for example, but following their time as an invalid, they will not only be healthy again, but also recover from any illness they might have had. One result of this is that if ichor is used as a bullet, warfare is 
Czigányik, Zsolt. "From the Bright Future of the Nation to the Dark Future of Mankind: Jókai and Karinthy in Hungarian Utopian Tradition." Hungarian Cultural Studies. e-Journal of the American Hungarian Educators Association, Volume 8 (2015): http://ahea.pitt.edu DOI: 10.5195/ahea.2015.213

constricted to the destruction of machinery, as the wounding of soldiers only leads in the long run to the improvement of the health of enemy soldiers. This forms the basis of the ending of the first part of Jókai's epic utopian novel, which sees one last limited war won by the Hungarians followed by international powers calling for the creation of a utopian state.

The second part of Jókai's novel (entitled "Az örök béke" ['Eternal Peace']) describes the life of the utopia achieved: a city called "Otthon" ['Home']. The utopian city encompasses 42 square miles at the lower part of the Danube (Dobruja), is inhabited by a million people, and is designed in an orderly manner, with orderliness representing a form of beauty, particularly through the garden culture the city exhibits. Of the many important effects "Home" has on the world, the military one proves to be crucial. Amongst the greatest negative impacts of warfare presented in the book are the disastrous economic effects of an arms race. When the invention of the undefeatable flying machine makes this race pointless, the effects on the economy are almost wholly positive, with large sums freed for non-destructive purposes. When "Home's" army proves to be undefeatable due to its unchallengeable air force, all major states have to give up their preparations for war. This means, amongst other things, the introduction of four million new workers to the European economy, which is interpreted optimistically as a boost as it does not lead to a rise in unemployment. The lack of warfare is seen as promoting the general good: an International Peace Tribunal is set up, and sovereigns submit to its rule as they lack "ultima ratio regum," leading to Europe growing closer to becoming a unified state. The generally peaceful nature of the narrative of Part Two disappears when (partly due to external propaganda) the harmony of the new state is threatened from below. This is the moment when (despite earlier denials) it becomes clear that a coercive force might be used even within the utopian state in case of mutiny (Jókai 1981: 216). The structure of society is described by Jókai in Marxist terms of patterns of exploitation, with the authorities - as it is to be expected of an exploiting classconstantly considering the use of coercive forces. The nature of this force is, however, unusual, including the fact that serious attempts are made to minimize casualties. Together with the airplane, a beneficial agricultural invention is employed as a mechanism of coercion: namely, the artificial creation of rain. This is developed into a method that creates a thunderstorm, leading to the dispersal of a mutinous group without casualties.

Eternal peace is reached by destroying the opponents of human progress in a huge war. With the mutiny suppressed, there remains only one opponent to the utopian existence of eternal peace; the forces of Nihil mentioned in the book's Preface and manifested in and represented by Russia. A war waged between Hungary and the Russians, who seek allies amongst the Slavic nationalities in the south of Hungary, is similarly fought with water, but in a much less humane manner than in the dispersal of mutineers. Using a method similar to that used by the Dutch, Tatrangi blocks the passage of the Danube at Vaskapu (Iron Gates, the narrows south-east of Belgrade) resulting in a catastrophic flood. This leads to the partial destruction of the Nihil armies and makes it impossible to attack Hungary from the south. But it also destroys the lands, houses and the lives of thousands of civilians. In one respect, this warfare is presented in its visual imagery as humanistic due to the lack of arms involved in the fight. But closer scrutiny reveals the inhuman nature of the destruction. This theatre of the war is fought by man's superhuman capability to block a major river and force it to flood large territories. Another theatre is the fight of flying machines against each other, where human intervention is almost redundant. The giant fight of airplanes must have been viewed as entirely fantastic by readers in the 1870s. A form of humanism is also present here: airplanes fight above water, so that the falling pilots will be saved (Jókai 1981: 263). The outcome of the war is the complete defeat of 
Czigányik, Zsolt. "From the Bright Future of the Nation to the Dark Future of Mankind: Jókai and Karinthy in Hungarian Utopian Tradition." Hungarian Cultural Studies. e-Journal of the American Hungarian Educators Association, Volume 8 (2015): http://ahea.pitt.edu DOI: 10.5195/ahea.2015.213

the Russian army partly by machines, and partly by the use of water. The defeat of the last army in the world marks the beginning of eternal peace.

\section{Individual Agency vs the Structural View of History}

Utopias essentially describe ideal political structures, but in The Novel of the Century to Come individual agency plays an equally important role. In Jókai's novel, the final utopian goal of eternal peace is achieved through the successes of individual endeavors, whereas utopias primarily deal with social and political structures (including the effects of technological progress), and are less concerned with individual agency. From a literary/aesthetic point of view, the structural orientation of positive utopias often results in a lack of well-developed characters and conflicts, and a proper narrative in utopian literature. The peculiarity of Jókai's book is that the essential, often deterministic structuralism of utopia is blended with an agency-centered attitude of a romantic writer who accepts the necessity of describing politico-economical structures in the genre of utopia, but essentially - as is typical of a writer of romantic fictionseeks for heroes and villains, action and conflict. Jókai claims that the "eternal peace" and ultimate happiness of mankind are partly the result of the ideal socioeconomic structure of the utopian state, and partly the magical qualities of the new material ichor. But at the same time, Jókai reveals that peace can only be achieved and maintained through the individual virtues of the main heroes. Dávid Tatrangi is depicted as an epic fairy-tale hero and a recurring element of the narrative is that his cunning defeats all opposing, negative powers.

It remains a question of debate whether individual intentions or structural forces shape human life and history, but such literary representations of society as utopias can hardly work without the prominence of individual agency. The protagonist's decisive role is in opposition with the structuralist view of history, most prominently expounded by György Lukács (1971: 221), who in his seminal work History and Class Consciousness claimed that events are controlled by profounder historical forces than individual action. The intentionalist-structuralist opposition was recently reinstated in a debate concerning the nature of revolutions, a debate that I find appropriate to extend to the more general problem of what shapes history and hence the frameworks of human life in general and as it is represented in utopian writing. Theda Skocpol claims that her understanding of social revolutions is "[n]onintentionalist at the macroscopic level [... as] there is no single acting group [...] that deliberately shapes the complex and multiply determined conflicts" (1994: 199). She understands Lukács's "profounder historical forces [...] beneath the surface as [...] structures, or patterned relationships beyond the manipulative control of any single group or individual" (1994: 200). Eric Selbin opposes Skocpol's (and Lukács's) views suggesting that "[t]he focus [...] needs to be on people, not structures, choices, not determinism"; and he calls for "the return of people and their ideas to a place of prominence in understanding and exploring revolutionary processes," claiming that "the failure to include the efforts and intentions of people assumes that structural conditions dictate absolutely what people can do" (1997: 123). An extreme, positivistic structuralism in the explanation of political and social matters seems not only alien from a romantic writer as Jókai, but generally quite unfruitful as an analytical tool in discussing utopian literature with a proper plot and characters. A naïve intentionalism disregarding the relevance of structural elements (including the development of technology) seems equally inappropriate for our needs. A viable "golden compromise" can be found in Selbin's conclusion where he claims that there is a "dialectical relationship between individual and collective will [...]. The interplay of circumstance and action - neither of which can exist without the other - creates human history" 
Czigányik, Zsolt. "From the Bright Future of the Nation to the Dark Future of Mankind: Jókai and Karinthy in Hungarian Utopian Tradition." Hungarian Cultural Studies. e-Journal of the American Hungarian Educators Association, Volume 8 (2015): http://ahea.pitt.edu DOI: 10.5195/ahea.2015.213

(1997: 133). As the case of Jókai shows, it might be suggested that the literary element in utopian literature naturally emphasizes the personal agency of individuals against structural elements in history. In twentieth century dystopia the limitedness of personal agency is transformed into the helplessness of the personal subject against the structural forces (cf. Winston Smith in Orwell's Nineteen Eighty-Four).

\section{Robots before Čapek}

The last literary work to be discussed in this short introduction into Hungarian utopianism is Utazás Faremidoba ['Voyage to Faremido'], a short, satirical piece written in 1916 by Frigyes Karinthy (1887-1938). Karinthy was a very popular and highly esteemed Hungarian writer, poet, and humourist. This story fits into the tradition of the creative reception of Swift's Gulliver's Travels, pretending to be a description of Gulliver's fifth journey, in which "the delightful adventures of an optimistic Mr Gulliver turn into the bitter history of a self-destructive humankind" (Hartvig 2013: 33). In this short satire (written four years before Karel Capek's famous $R$. U. R., the play that introduced the word 'robot'), Gulliver leaves his family in 1914 on a navy boat. The ship hits a mine and begins to sink, but Gulliver is rescued by a strange flying machine. When he regains his consciousness, he finds himself in an unknown place, hearing a harmonious melody: $f, d, e, c$, or on the sol-fa scale: $f a-r e-m i-d o$ - hence the title of the book and the name of the country. The environment is ultimately harmonious and peaceful-this is expressed by the music heard - but all other features of the mysterious land also exhibit a powerful harmony, including the sophisticated machines found around the place. The machines generally incite a delightful feeling, and are in fact beautiful, prompting Gulliver to emotions not unlike love. He senses a special power surrounding the machines, and naturally begins both looking for the people that control them and imagining the creators of these supreme mechanical constructions as highly developed humans. Gulliver is by no means an omniscient narrator, but rather a surrogate reader that (similarly to H. G. Wells's time traveler) discovers the strange land step by step, making false assumptions about the phenomena he discovers as he goes. Thus, it takes some time until he recognizes that the machines of Faremido not only have no human drivers or pilots, no human or organic masters, but in fact are the only inhabitants of the country. And, despite their inorganic nature and the lack of biological vitality, the machines consider themselves to be a higher level of existence than organic life. In fact, organic life is considered not only less valuable than mechanic existence, but indeed unnatural and incapable of the happy and harmonious existence of the inorganic intellect. The perfect working of the intellect is the ultimate aim of the machine-world, and human life is seen as seriously threatening this perfection.

Gulliver's process of understanding the world of Faremido culminates in a philosophical discussion on the nature of machines and the relationship between man and machine. Machines were originally constructed to help man in all their actions and to enhance their abilities. Yet with their development, they began to work in a much more perfect fashion than their human counterparts. A parallel is made to art, which is considered to be able to create perfected phenomena (color, narrative, or emotion) compared to the ones existing outside the realm of art. Machines exceed man, and a point is reached where the way for humans to perfect themselves is to imitate the machines that originally had meant to imitate humans. A circle of simulacrum is described here, where the imitable becomes the imitating subject. The discussion continues to combine the reflection on the roles of machines and that of artistic creations: a painting may be worth much larger sums than the model for the paining - humans are not paid the same dignity 
Czigányik, Zsolt. "From the Bright Future of the Nation to the Dark Future of Mankind: Jókai and Karinthy in Hungarian Utopian Tradition." Hungarian Cultural Studies. e-Journal of the American Hungarian Educators Association, Volume 8 (2015): http://ahea.pitt.edu DOI: 10.5195/ahea.2015.213

as certain artefacts. Humans begin to value their own creations higher than themselves, and in all their creations one principle is followed; to create a more and more perfect man. Yet parallel to machines becoming perfect, the human race does more and more to destroy the planet Earth, which is also presented by Karinthy as an inorganic, supreme machine. The only hope for the survival of the planet is the foreseeable complete self-destruction of mankind. The external point of view provided through this utopian distancing results in an ultimately bitter satire (exceeding Swifts' original model): a harmonious, non-violent world is only possible without mankind, the ultimate destructive and self-destructive force in the universe.

The role of technology features as most important in a number of Hungarian utopias, but its interpretation changes significantly by WWI. For Mór Jókai, the late nineteenth century romantic writer, the construction of a reliable airplane brings eternal peace to mankind. A generation later, with the experience of the destruction by military aircraft in WWI, machines replace man, who is then left for self-destruction. Technology thus prevails, but not to the benefit of mankind. The utopian optimism of Jókai gives way to dystopian pessimism not unprecedented in utopian writing, as seen especially in Madách's The Tragedy of Man, where all development (not necessarily technological) results only in new mechanisms for human misery. This attitude will be prevalent in twentieth century Hungarian dystopian writing, particularly in the works of Sándor Szathmári, an admirer and disciple of Karinthy, but this is a story to be discussed in another paper.

\section{Works cited}

Abensour, Miguel. 2008. "Persistent Utopia." Constellations 15.3: 406-21.

Baccolini, Rafaela and Tom Moylan. 2003. "Dystopia and Histories.” In Dark Horizons. Science Fiction and the Dystopian Imagination. Eds. Rafaela Baccolini and Tom Moylan. London: Routledge. 1-12. 2003. "Critical Dystopia and Possibilities." In Dark Horizons. Science Fiction and the Dystopian Imagination. Eds. Rafaela Baccolini and Tom Moylan. London: Routledge. 233-250.

Bessenyei, György. 1953. Válogatott müvei ['Selected Works’]. Budapest: Szépirodalmi Könyvkiadó.

Booker, Keith. 1994. The Dystopian Impulse in Modern Literature. London: Greenwood Press. Czigány, Lóránt. 1984. The Oxford History of Hungarian Literature. Oxford: Clarendon Press. D. Zöldhelyi Zsuzsa. 1981. "Jegyzetek" ['Notes']. In Jókai Mór. A jövő század regénye ['The Novel of the Century to Come'] Vol 2. Budapest: Akadémiai Kiadó. 533-911.

Gottlieb, Erika. 2001. Dystopian Fiction East and West. Montreal: McGill-Queen's UP. Hartvig, Gabriella. 2013. The Critical and Creative Reception of Eighteenth-Century British and Anglo-Irish Authors in Hungary. Pécs: University of Pécs.

Jókai, Mór. 1981 [1872-74]. A jövö század regénye ['The Novel of the Century to Come'] Vols. 1-2. Budapest: Akadémiai Kiadó.

Karinthy, Frigyes. 1965 [1916]. Voyage to Faremido; Capillaria. Budapest: Corvina.

Kumar, Krishan. 1987. Utopia and Anti-Utopia in Modern Times. Oxford: Basil Blackwell. Lukács, György. 1971 [1923]. History and Class Consciousness. Cambridge, Mass.: The MIT Press.

Sargent, Lyman Tower. 1994. “The Three Faces of Utopianism Revisited.” Utopian Studies 5.1: 1-37. 
Czigányik, Zsolt. "From the Bright Future of the Nation to the Dark Future of Mankind: Jókai and Karinthy in Hungarian Utopian Tradition." Hungarian Cultural Studies. e-Journal of the American Hungarian Educators Association, Volume 8 (2015): http://ahea.pitt.edu DOI: 10.5195/ahea.2015.213

Schaer, Roland. 2000. “Utopia: Space, Time, History.” Utopia: The Search for the Ideal Society in the Western World. Eds. Roland Schaer, Gregory Claeys, Lyman Tower Sargent. New York: The New York Public Library and Oxford UP, 3-7.

Selbin, Eric. 1997. "Revolution in the Real World: Bringing Agency Back in." Theorizing Revolutions. Ed. John Foran. London: Routledge. 123-136.

Skocpol, Theda. 1994. Social Revolutions in the Modern World. Cambridge: CUP, 1994. Steiner, George. 2013 [1975]. After Babel. New York: Open Road Integrated Media.

Veres, Miklós. 2013. "A képzelet derült játékai”" ['Blissful plays of fantasy'] Holmi 25.1: 67-82. Vieira, Fátima. 2010. "The Concept of Utopia.” The Cambridge Companion to Utopian Literature. Ed. Gregory Claeys. Cambridge UP, 3-27. 